\title{
Bladder Cancer pN1 TNM Finding v6
}

National Cancer Institute

\section{Source}

National Cancer Institute. Bladder Cancer pN1 TNM Finding v6. NCI Thesaurus. Code C61221.

Bladder cancer with metastasis to a single lymph node with a size of $2 \mathrm{~cm}$ or less in greatest dimension. Regional lymph nodes are those within the true pelvis. All other lymph nodes are distant lymph nodes.(from AJCC 6th Ed.) 